\title{
A POLÍTICA DE CARIDADE, ASSISTÊNCIA E PROTEÇÃO À INFÂNCIA DESVALIDA EM BELÉM DO PARÁ: DO IMPÉRIO À REPÚBLICA
}

\author{
Laura Maria Silva Araújo Alves
}

\section{RESUMO}

O objetivo deste artigo é trazer a lume a política de caridade, assistência e proteção à infância desvalida em Belém do Pará, do período que se estende do Império à República. No século XIX, a infância deveria ser assistida na capital do Pará em decorrência da política idealizada e implementada pela elite paraense. Assim, a infầncia que precisava ser assistida era designada de "órfâ" e "exposta". A primeira, dizia respeito, também, à criança que tinha perdido um dos pais, e a segunda, chamada, também, "enjeitada" ou "desvalida", correspondia à criança que alguém não quis cuidar ou receber. Este artigo está divido em três partes. Na primeira, situo a cidade de Belém do Pará, em termos políticos, econômicos e sociais, no cenário do Brasil República, em interface com a infância. Na segunda parte, destaco as políticas assistenciais e filantrópicas no atendimento à infância no Pará e o ideário higienista. E, por fim, na terceira, trago à cena algumas instituições que foram criadas em Belém do Pará, no período do Império à República, para abrigar a criança órfã e desvalida.

Palavras-Chave: Grão Pará. Infância. Crianças Desvalidas. Higienismo. Filantropia. Assistencialismo.

\section{ABSTRACT}

The objective of this article is to bring to light the charity, assistance and protection policy for disfavored childhood in Belém-PA, from the period of the Empire to the Brazilian Republic. In the $19^{\text {th }}$ century, children should be assisted in the capital of the state of Pará as a result of the political idealization implemented by this state's elite. Therefore, the ones who needed to be assisted were designated as "orphans" or "exposed". The former ones, not exclusively, were the children who had lost one of their parents; the latter ones, also referred to as "rejected" or "disfavored", corresponded to the children none would look after or welcome. This article is divided into three parts. In the first, the city of Belém is situated in political, economic and social terms, interfaced with childhood, in the scenario of the Brazilian Republic. In the second, the assistance and philanthropic policies for childhood care, as well as the hygienist ideas, are highlighted. Finally, institutions created to shelter orphan and disfavored children in Belém, from the period of the Empire to the Republic, are brought to centre stage.

Keywords: Grão Pará; Childhood; Disfavored Children; Hygienism; Welfarism; Philantropy.

Psicóloga, Pesquisadora e Professora Associada III da Universidade Federal do Pará. Desenvolve pesquisas na área da História da Infância na Amazônia paraense, no Programa de Pós-Graduação em Educação da UFPA. 


\section{INTRODUÇÃO}

O objetivo deste artigo é trazer a lume a política de caridade, assistência e proteção à infância desvalida em Belém do Pará, do período que se estende do Império à República. No século XIX, a infância deveria ser assistida na capital do Pará em decorrência da política idealizada e implementada pela elite paraense. Assim, a infância que precisava ser assistida era designada de "órfã" e "exposta". A primeira, dizia respeito, também, à criança que tinha perdido um dos pais, e a segunda, chamada, também, "enjeitada" ou "desvalida", correspondia à criança que alguém não quis cuidar ou receber. Para o final do século, o termo "desvalido" passou a ser mais utilizado, significando a criança miserável (RIZZINI, 2009). É importante destacar que no século XIX não existia uma relação direta entre a falta de condição dos pais em criar os filhos e o abandono, pois nem todas as crianças pobres da capital do Pará eram deixadas nas instituições de abrigamento. Muitos pais, por razões relacionadas à ausência de recursos materiais para criá-las, recorriam a essas instituições como uma forma de seus filhos receberem uma educação profissional.

Por todo o Brasil a infância abandonada deveria ser assistida pelas Misericórdias, por meio da Roda e Casa dos Expostos, e pelas políticas de assistência das províncias. Maria Luiza Marcilio (1998, p. 134), assim define o sistema social da caridade:

Do período colonial até meados do século XIX vigorou a fase [...] caritativa. $\mathrm{O}$ assistencialismo dessa fase tem como marca principal o sentimento da fraternidade humana, de conteúdo paternalista, sem pretensão a mudanças sociais. De inspiração religiosa, [...] privilegiam a caridade e a beneficência. Sua atuação se caracteriza pelo imediatismo, com os mais ricos e poderosos procurando minorar o sofrimento dos mais desvalidos, por meio de esmolas ou das boas ações [...], esperam receber a salvação de suas almas, o paraíso futuro e, aqui na terra, o reconhecimento da sociedade e o status de beneméritos. Ideologicamente, procura-se manter a situação e preservar a ordem, propagando-se comportamentos conformistas.

Para Marcílio (1998) e Venâncio (1999), a história da institucionalização da assistência à infância no Brasil foi dividida em três fases: caritativa, filantrópica e de bem-estar social. A fase caritativa foi amplamente difundida no Brasil Colonial, originando um grupo com status social indefinido, os chamados "filhos de criação". 
Em meados do século XVIII, são fundadas as primeiras instituições de assistência à infância, como roda dos expostos e casas de recolhimento para meninas pobres geridas pelas Irmandades das Misericórdias (NASCIMENTO, 2008).

A segunda fase da institucionalização da assistência à infância, denominada filantropia, foi marcada pela tímida presença do Estado na organização do movimento de assistência, quando as províncias do Império implantaram um novo modelo, que incluía a instrução primária e a profissional para meninos e meninas. É, justamente, nessa fase que a saúde da infância tornou-se o principal foco das instituições de assistência, e os médicos, como homens de ciência, exerceram um papel relevante no combate à mortalidade infantil e nos cuidados com a mulher mãe de família.

Já a fase de bem-estar social se dissemina no século XX. As políticas destinadas à infầncia, no Estado Novo, configuraram ações de tutela e proteção, ampliadas pela regulamentação e pela criação de diversas instituições públicas voltadas à primeira infância (RIZZINI, 2008; SCHUELER, 2002).

No contexto do Pará, muitas instituições foram criadas para o acolhimento das crianças abandonadas e órfãs. Contudo, a responsabilidade de assistir à infância paraense recaiu sobre a iniciativa religiosa. Muitas congregações abraçaram a missão de cuidar e educar um contingente de crianças órfãs e enjeitadas. Ainda no Pará, nos finais do século XIX, os médicos com as políticas higienistas foram sobremaneira relevantes para o atendimento da infância com medidas que pretendiam diminuir a mortandade infantil. Eles defendiam práticas educativas que tinham o intuito de salvar a criança com o conhecimento da ciência. A medicina higienista e filantrópica atuou, a partir de 1870, baseada em modelos de assistência à infância em fóruns nacionais e internacionais e ancorados no espírito nacionalista da época.

É a partir desse contexto de atendimento à criança em Belém do Pará que questionamos: Que medidas higienistas foram implementadas no cuidado com a infância na capital do Pará? O que trouxeram de mudanças os médicos higienistas e sanitarista para a infância paraense nesse contexto desolador de mortandade infantil? Que instituições foram criadas do Império à República em Belém do Pará para atender a infância órfã e desvalida?

O presente artigo está divido em três partes. Na primeira, situo a cidade de Belém do Pará, em termos políticos, econômicos e sociais, no cenário do Brasil República, em interface com a infância. Na segunda parte, destaco as políticas assistenciais e filantrópicas no atendimento à infância no Pará e o ideário higienista. 
E, por fim, na terceira, trago à cena algumas instituições que foram criadas em Belém do Pará, no período do Império à República, para abrigar a criança órfã e desvalida.

\section{SITUANDO A BELÉM do PARÁ do INÍCIO do SÉCULO XX E A INFÂNCIA}

Para começar a falar da infância na Belém do Pará do Império à República trago um poema de Manoel Bandeira, publicado em 1928, após uma visita à capital do Pará. Diz Manuel Bandeira:

\section{BELÉM DO PARÁ}

Bembelelém!

Viva Belém!

Belém do Pará porto moderno integrado na equatorial

Beleza eterna da paisagem

Bembelelém!

Viva Belém!

Cidade pomar

(Obrigou a polícia a classificar um adjetivo novo de delinqüente:

$\mathrm{O}$ apedrejador de mangueiras)

Bembelelém!

Viva Belém!

Belém do Pará onde as avenidas se chamam Estradas:

Estrada de São Gerônimo

Estrada de Nazaré

Onde a banal Avenida Marechal Deodoro da Fonseca de todas

[as cidades do Brasil

Se chama liricamente

Brasileiramente

Estrada do Generalíssimo Deodoro

Bembelelém!

Viva Belém!

Nortista gostosa

$\mathrm{Eu}$ te quero bem.

Terra da castanha

Terra da borracha

Terra de biribá bacuri sapoti

Terra de fala cheia de nome indígena

Que a gente não sabe se é de fruta pé de pau ou ave

[de plumagem bonita. 
Nortista gostosa

$\mathrm{Eu}$ te quero bem.

ME obrigarás a novas saudades

Nunca mais me esquecerei do teu Largo da Sé

Com a fé macinça das duas maravilhosas igrejas barrocas

E o renque ajoelhado de sobradinhos coloniais tão

[bonitinhos

Nunca mais me esquecerei

Das velas encarnadas

Verdes

Azuis

Da doca de Ver-o-Peso

Nunca mais

E foi pra me consolar mais tarde

Que inventei esta cantiga:

Bembelelém!

Viva Belém!

Nortista gostosa

Eu te quero bem.

Manuel Bandeira, Belém, 1928

Esse poema de Manuel Bandeira traz, com bom humor e muito lirismo, o encantamento por Belém do Pará. Ao longo do poema, repete-se sonoramente o refrão que se vale da onomatopéia evocada pelo nome da cidade: "Bembelelém/ Viva Belém!". Esta é a Belém do Pará dos anos 20 do século passado: terra tropical; presença portuguesa; porto moderno; frutas exóticas; terra da castanha, da borracha, de igrejas barrocas e sobrados coloniais; cidade das velas coloridas e da doca de "Ver-o-Peso".

Em Belém, o poeta descobre um outro Brasil desconhecido do resto do país. Assim como Manuel Bandeira, Mario de Andrade, na mesma proporção de encantamento por Belém dos anos 20, expressou o seu amor à capital paraense numa carta que enviou ao amigo escritor Manu (Manuel Bandeira) na qual confidencia as suas mais sinceras impressões por Belém. Diz Mario na carta escrita em 1927:

Manu, estamos numa paradinha pra cortar canarana da margem pros bois dos nossos jantares. Amanhã se chega em Manaus e não sei que mais coisas bonitas enxergarei por este mundo de águas. Porém, me conquistar mesmo, a ponto de ficar doendo no desejo, só Belém me conquistou assim. Meu único ideal de agora em diante é passar uns meses morando no Grande Hotel de Belém. O direito de sentar naquela terraça em frente das mangueiras tapando 
o Teatro da Paz, sentar sem mais nada, chupitando um sorvete de cupuaçu, de açaí. Você que conhece mundo, conhece coisa melhor do que isso, Manu? [...]. Belém eu desejo com dor, desejo como se deseja sexualmente, palavra. Não tenho medo de parecer anormal pra você, por isso que conto esta confissão esquisita, mas verdadeira, que faço de vida sexual e vida em Belém. Quero Belém como se quer um amor. É inconcebível o amor que Belém despertou em mim. (ANDRADE, 1927, p.)

Ambos falam de uma Belém do Pará que, embora já com o declínio da economia da borracha, ocorrido por volta de 1920, ainda encantava os viajantes, poetas, cientistas, empresários, comerciantes e muitos estrangeiros que chegavam à metrópole da Amazônia. Manuel Bandeira e Mario de Andrade, em suas passagens pela capital do Pará, destacaram aspectos da cidade que desde os finais do século XIX, vinha atraindo pessoas em decorrência da situação econômica advinda da comercialização da borracha, que passou a receber medidas de embelezamento da cidade e que atraía a todos pelo progresso e pela ideia de civilização (CANCELA, 2008). A carta de Mario de Andrade e o poema de Manuel Bandeira estão repletos de detalhes mostrando o valor de Belém no cenário nacional e internacional, que a fez ser conhecida como a "francesinha do Norte".

A imagem visual da cidade de Belém misturava aspectos provincianos com ar de modernidade, ressaltadas pelos poetas, bem de acordo com as noções de progresso da época. Possivelmente, essas características foram intencionalmente confeccionadas baseadas em uma concepção de cidade que permeou todo o trajeto de sua construção, marcado por ações políticas para deixar a cidade bastante atraente. Tudo isso, pela riqueza criada pelo látex, que contribuiu significativamente para uma reorganização do espaço urbano e para migração de muitos estrangeiros (SARGES, 2002).

O embelezamento visual da capital do Pará, narrado na carta de Mario de Andrade, estava diretamente ligado à economia da borracha e a ampliação populacional. Assim, as ações estabelecidas pelo intendente Antônio Lemos, no início do século XX, intencionavam deixar a cidade com aspectos de uma cidade moderna, e oferecer, ao segmento da população em ascensão, uma cidade sem problemas socais e muito segura. Para isso, Antônio Lemos teve que (re)planejar a cidade para ter seu espaço disciplinado, e, para isso, estabeleceu regulamentos (Código de Posturas) da vida social na cidade. Como se vê, toda essa idealização do intendente estava associada aos valores estéticos de uma classe social em ascensão 
composta por seringalistas, comerciantes, fazendeiros e intelectuais (SARGES, 2002).

Projetar Belém nos finais do século XIX como uma cidade civilizada exigia de Antônio Lemos medidas de planejamento de reforma principalmente sobre os hábitos da população. $\mathrm{O}$ intendente constatou que grande parte dos belenenses, sobretudo, da população pobre, não possuía um comportamento civilizado compatível com os modelos de comportamentos dos europeus. Diante dessa situação, o intendente se utilizou de mecanismos capazes de prover as necessidades educacionais da população para evitar o "mau comportamento", como evitar: chamar palavrões em ruas e vias públicas, jogar lixo nas ruas, não haver mendicância, evitar a vadiagem de jovens, embriaguez, prática de prostituição, jogos, aglomerações de pessoas, gritarias, gargalhadas, batuques e sambas, crianças brincando na rua e praças, dançar em cordões de pássaros fora da época carnavalesca etc. (SILVA, 2009).

Nesse contexto dos anos 20 do século passado que foi referenciada pelos poetas sobre a capital do Pará, encontrava-se a criança. Embora com todo o embelezamento da cidade e sua prosperidade, a mortalidade infantil era intensa. $\mathrm{O}$ óbito de crianças foi considerado à época como um sério problema, muito por conta da miséria, da pobreza e da falta de conhecimentos voltados para alimentação e cuidados com a higiene da criança, bem como pela própria fragilidade física destes pequenos sujeitos (DEL PRIORE, 1999). Sabe-se que na primeira década do século $\mathrm{XX}$ apenas uma pequena parcela de crianças chegava à vida adulta.

A pesquisa realizada por Alves, Chagas e Viana (2015) nos Livros Perpétuos de Sepultamento de Menores no Cemitério de Santa Isabel que trata do número de óbitos de criança, ilustra essa realidade frágil da infância, ao evidenciar que, no período de 1908 a 1911, existia um assustador índice de mortandade de crianças na capital do Pará. Muitas crianças morriam ainda na primeira infância de diversas doenças como: infecção intestinal, gastroenterite, febre intermitente, infecção pulmonar, dentição, diarreia, verminoses etc.

Em decorrência do grande número de óbitos de crianças, as famílias apressavam o batismo para os primeiros dias de vida, pois já contavam com a morte breve delas. As mães ficavam aflitas quando suas crianças ficavam doentes, pois a morte em geral batia na porta das famílias pobres. Dalcídio Jurandir (1941), nosso maior escritor amazônico, retrata no seu romance Chove nos Campos de Cachoeira uma passagem da pequena Mariinha, irmã do menino Alfredo, personagem central 
do romance, que vivia escapando da morte deixando a sua mãe, D. Amélia, cada dia mais aflita com a saúde delicada de sua filha. Diz o narrador:

Mariinha todo mundo dizia que não se criava. D Amélia (mãe), levava noites e noites, sozinha [...] velando o sono da Mariinha com febre. Era pano com vinagre, era lavagem, era defumação. Dona Maria dos Navegantes foi a primeira que disse: - Ah, D. Amélia, paciência, mas essa menina não se cria. Parece de sete meses. Alfredo media a grossura do bracinho dela pelo dedo polegar. Tudo em Mariinha era mole, frágil, sem vida mesmo. Mas D. Amélia perdia noites ao pé da filha. [...] Alfredo saia da rede, pé-ante-pé, para espirar, pelas frestas da porta do quarto, se Mariinha estava mal. Mariinha morria e vivia. [...] perder Mariinha era o que toda a hora podia acontecer (JURANDIR, 1941, p.302$303)$.

Assim como a mãe Mariinha, muitas mães viviam o assombro diante da morte frequente de filhos. A fragilidade de Mariinnha era a mesma de muitas crianças, não somente da região do Marajó, mas também a da capital onde se tinha assistência à saúde com as ações dos médicos higienistas. Além das epidemias, falta de sistema de esgotamento sanitário, precariedade dos sistemas de abastecimento de água, condições miseráveis das habitações, hábitos inadequados de higiene e problemas com a alimentação da criança, os médicos condenavam ainda práticas culturais que prejudicavam o desenvolvimento da criança.

\section{POLÍtica HIGIENISTA NOS CUIDAdOS COM A CRIANÇA EM BELÉM DO PARÁ}

No início do século XX, a ciência moderna começa a se preocupar com a mortalidade de crianças, ao produzir estudos referentes às descobertas da origem de muitas doenças, assim como de métodos preventivos e medicamentos para tratá-las, e no caso da infância, especificamente, alguns pesquisadores começaram a produzir estudos voltados para esse seguimento social, os quais se referiam à alimentação da criança, à saúde das mães, ao parto, às peculiaridades do recém-nascido, ao banho, às vestimentas e, sobretudo, às pesquisas que se ocuparam das doenças que mais acometiam as crianças (ALVES, 2012).

Com o raiar da República nos finais do século XIX e início do XX, a mortandade infantil tornou-se um problema mais intensamente discutido, uma vez que a infância foi concebida como o "embrião" do país, o sujeito que necessitava ser "saudável", "forte" e "robusto" para ser capaz de contribuir para o progresso da 
Nação, por isso, as crianças, enquanto "as sementes do futuro", necessitavam ser cuidadas e higienizadas.

É nesse cenário que surge a preocupação com a infância, que passava a ser considerada importante para o progresso e desenvolvimento do país, ou seja, descobre-se a infância, e a necessidade de se constituir uma sociedade sadia, moral e fisicamente forte, que pudesse dar continuidade aos processos de modernização do Brasil (ARAÚJO, 2014).

Nesse contexto republicano, surgem as ideias relacionadas à Puericultura, com um discurso médico de preocupações com a alimentação, brinquedos, tratamento diferenciado, dentição, desenvolvimento físico e moral da criança. Portanto, em razão da grande mortalidade infantil houve por parte dos higienistas e sanitaristas a emergência de se promover a conscientização de que as crianças necessitavam receber cuidados especiais. Em Belém, a problemática da elevada mortandade das crianças era algo inaceitável pela elite urbana reformista, uma vez que estava em desacordo com os anseios republicanos de ordem e progresso instalado em todo o Brasil.

Vale ressaltar que foi no século XIX, em decorrência da urbanização que os médicos passaram a se preocupar com mais intensidade com os cuidados e a higiene dos locais e das pessoas, tais como: a localização de cemitérios, controle dos espaços físicos, controle das epidemias, principalmente, os cuidados com a criança e as mulheres. A grande preocupação era neutralizar os perigos que ameaçavam a saúde da sociedade. As medidas higienistas abrangiam os cuidados com a saúde da criança nos primeiros anos de vida, cuidados com a gravidez e o parto, além de cuidados com a amamentação realizada pelas amas de leite (FERREIRA; GONDRA, 2007).

Com a exploração da borracha na Amazônia nos finais do século XIX, a sociedade da capital paraense não estava dissociada do contexto nacional e viviam grandes transformações nos campos político, econômico e cultural. Essa economia provocou um intenso processo migratório, fazendo com que a população de Belém crescesse consideravelmente. Eram pessoas vindas de muitas partes do Brasil e do exterior, que traziam consigo suas crianças e procuravam, mediante as dificuldades enfrentadas, um lugar para acolhê-las. Tal acontecimento obrigava o poder público a tomar diferentes medidas para garantir a ordenação da cidade de Belém e atender a uma elite formada pelos barões da borracha, que impunha um novo modelo de vida baseado em ideias trazidas das cidades europeias. Ao tempo em que a população 
crescia em um ritmo frenético, normas eram estabelecidas para que nada interferisse no projeto de modernização na capital do Pará.

A concepção médico-higienista, que embasava o projeto civilizador do final do século XIX, e que se estendeu para as primeiras décadas do século XX, estabelecia muitas diretrizes para a formação de uma nova sociedade e a capital da província do Grão Pará e depois o estado do Pará, a ela não esteve alheia, muito pelo contrário. A criança era o foco principal para o estabelecimento dessa nova sociedade e as ações de assistências e proteção começavam a ser pensadas para elas (BORDALO, 2000).

Nas propagandas do Jornal Folha do Norte, de 1900, observamos bem a preocupação em combater as parasitoses e o raquitismo das crianças com as propagandas do "Vermífugo Paraense" e "Emulsão de Scott" (Foto1). Nas propagandas, notamos um discurso em que há uma preocupação em proteger a saúde das crianças que, no início do século XX, morriam acometidas por verminoses. As propagandas dos referidos remédios davam destaque a sua eficácia no combate as verminoses, anemias e raquitismo das crianças (PINHEIRO, 2013).

Foto 1: Propaganda de "Vermífugo Paraense" e "Emulsão de Scott"
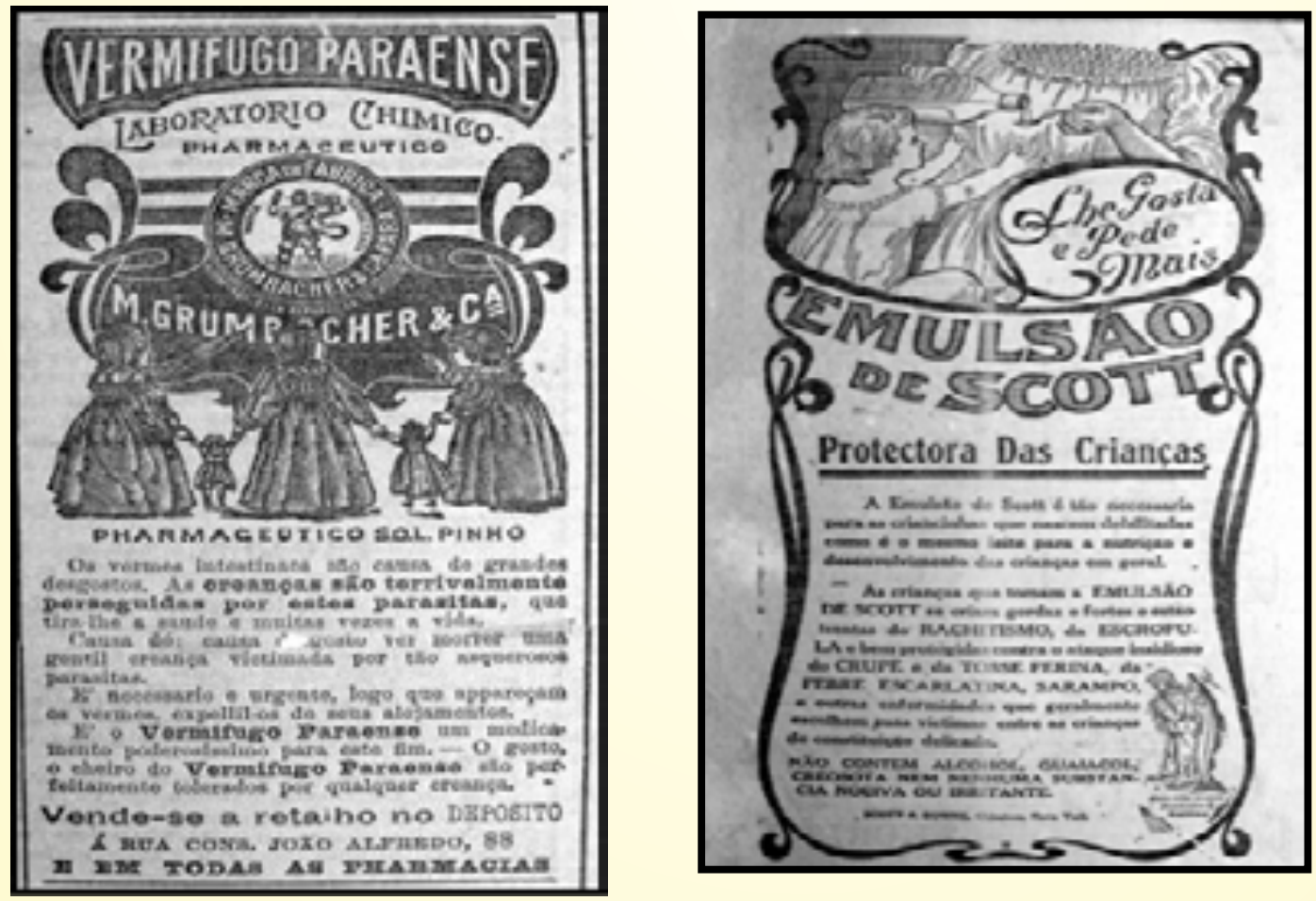

Fonte: JORNAL FOLHA DO NORTE, jul. 1909. 
No Pará do início do século XX, em razão da economia da borracha, houve uma migração de estrangeiros para a Amazônia, particularmente para a cidade de Belém. Esses imigrantes traziam consigo suas crianças, a maioria de classe pobre e já apresentando um estado de saúde debilitado pela má alimentação e condições de vida. Atrelado às condições físicas fragilizadas, as crianças eram vítimas de epidemias e de doenças infectocontagiosas, doenças trazidas pela miséria, má alimentação e falta de cuidado.

Assim, muitas medidas caritativas, de assistência e proteção à infância desvalida em Belém do Pará foram pensadas para "salvar a criança". As políticas caritativas e de assistência à infância começaram a ser implementadas no período de início do "boom da economia da borracha" (1850-1912). A partir dos anos de 1850, muitas instituições foram criadas para abrigar as crianças consideradas perigo para a sociedade paraense.

Para Rizzini (2008), esses espaços destinados ao acolhimento e ao cuidado de meninos e meninas órfãs e abandonadas sofreram mudanças de cunho ideológico, especialmente no Brasil, na passagem do século XIX para o XX, quando as práticas em relação à assistência foram incorporadas ao discurso e à ação dos higienistas, provocando o esmorecimento do caráter da misericórdia.

Essas instituições de caridade de natureza filantrópica que, num primeiro momento tinham caráter assistencialista, passaram a assumir, também, a missão de instruir seus internos, oferecendo, no caso das meninas, conhecimentos rudimentares em primeiras letras, práticas manuais e aprendizagens domésticas. Essa estratégia serviu para afastar das ruas muitas crianças que começavam a causar transtornos e má impressão aos moradores dos emergentes centros urbanos, principalmente das principais cidades brasileiras, que se encontravam em processo de formação (FERREIRA \& FREIRE, 2011).

\section{CRIAÇÃO DE INSTITUIÇÕES DE ASSISTÊNCIA E PROTEÇÃo À INFÂNCIA EM BELÉM DO PARÁ DO SÉCULO XIX AO INÍCIO DO SÉCULO XX}

Como palco de atuação de medidas filantrópicas, de assistência e proteção à infância, Belém do Pará se destaca no cenário brasileiro com a criação de diversas instituições de abrigamento de criança ao longo do século XIX e início do século XX. Metade das instituições criadas na Primeira República era custeada pela 
filantropia e, a outra metade, pelos poderes públicos. Floresceu na capital do Pará as ações filantrópicas que refletiam o dever de socorrer os mais necessitados (MARQUES, 2000).

No contexto da infância paraense houve um esforço das elites locais em assumir os cuidados e educação de crianças órfãs e desvalidas. Enfim, nos primeiros anos da República, a infância em Belém do Pará adquiria importância por representar o futuro. Para atingir esse ideal, a criança deveria ser preservada tanto em seu nascimento quanto nos primeiros anos de vida. Nesse ambicioso projeto, engajaramse, principalmente, os médicos sanitaristas e higienistas e as mulheres da elite local envolvidas em movimentos filantrópicos de amparo à infância.

A seguir destaco algumas instituições que tiveram papel importante na educação de meninos e meninas em Belém do Pará, como: Casa de Educandos Artífices, Companhia de Aprendizes Marinheiros, Colégio Nossa Senhora do Amparo, Orpahanato Paraense e Instituto de Proteção e Assistência à Infância do Pará. Para tal, recorri aos seguintes autores: Barbosa (2011), Araújo (2014), Sabino (2012), Monteiro (2013), Pinheiro (2014) e Alves (2012).

\subsection{Casa dos educandos artífices}

A Casa de Educandos Artífices foi criada para atender a classe de meninos desvalidos e pobres enjeitados, a fim de oferecer instrução profissional e educacional, tais como as noções das primeiras letras e noções de aritmética entre outras atividades. A criação dessa instituição visava retirar a população de menores incivilizada das ruas para outro enquadramento social, pois, direcionando os menores desvalidos a uma ocupação útil, a sociedade estava cumprindo com a formação de indivíduos civilizados.

Na Província do Pará em 1840, foi instalada a primeira Casa de Educandos Artífices do Brasil. Este estabelecimento denominado "Casa" preparava os meninos para vida profissional "ofícios de carpinteiro de machado, calafete, marceneiro, poleiro, funileiro e sapateiro". Os menores tinham uma rotina a seguir, pois era um cenário ditado por regras e disciplinas, contudo, esta política de controle trazia sérias consequências a estes meninos desvalidos que sofriam profundos maus tratos em relação às práticas punitivas entre elas: jornadas de trabalho extensas, privação de intervalo, isolamento, prisão, uso da palmatória entre outras. Nas últimas décadas do século XIX, foi introduzido o aprendizado de tipografia. Novas matérias foram 
adotadas, conforme as necessidades profissionais da época, como o desenho e geometria (BARBOSA, 2011).

$\mathrm{Na}$ Casa de Educandos Artífices do Pará, os alunos viviam sob uma política rígida de controle com horários apropriados para estudo, alimentação, descanso e jornada de trabalho. Mesmo com os estabelecimentos de regras regidas pelo regulamento do estabelecimento, tal prática não garantia a disciplina dentro da Casa "constantes as contravenções da ordem pelos alunos". Devido haver resistência dos alunos acerca da aceitabilidade do confinamento e a obediência dos meninos desvalidos, os diretores solicitavam que fossem instaladas prisões para separar os alunos mais novos dos maiores. Dessa maneira, os alunos que mantivesse uma má conduta dentro dos estabelecimentos de ensino eram severamente punidos. Portanto, havia um rígido controle sobre os meninos que vez ou outra se rebelavam às normas comportamentais da instituição.

No mais, o trabalho desenvolvido pelos meninos era amplamente aproveitado pela elite local. Têm-se notícias que parte das cadeiras do imponente Teatro da Paz e o portão de ferro do magnífico Colégio Gentil Bittencourt foram confeccionados pelos meninos da instituição. Como se vê, os meninos de certa maneira foram explorados com a produção de seus trabalhos.

\subsection{Companhia de aprendizes da marinha}

No século XIX, o governo imperial cuidou da educação na Corte e das necessidades de suas instituições, especialmente as da Marinha e do Exército, ao criar em todo o país Companhias de Aprendizes Marinheiros e Escolas/Companhias de Aprendizes dos Arsenais de Guerra. Os Arsenais de Guerra recebiam meninos dos colégios de órfãos e da casa de educando, que lá iam receber treinamento nas oficinas (RIZZINI, 2009).

As Companhias de Aprendizes Marinheiros, que eram escolas do tipo internato recebiam meninos recolhidos nas ruas pelas polícias das capitais brasileiras. O número de meninos enviados pelas companhias imperiais aos navios de guerra foi maior do que o de homens recrutados e voluntários.

Nos anos de 1870 a 1910, a sociedade brasileira vivenciou uma realidade marcada pelo crescimento desenfreado de casos de menores ligados ao crime. Furtos, esfaqueamentos, defloramentos, entre outros, eram os delitos cometidos com frequência por crianças e adolescentes. Diante da crescente marginalidade, o Estado 
foi pressionado a dar uma resposta para solucionar este problema na cidade, buscando melhorá-la por meio da criação de uma rede assistencial que auxiliasse os mais necessitados. Essa cultura filantrópica era regida por normas jurídicas e assistencialistas, o que gerou pormenorizar a questão da criminalidade da criança e do adolescente para a criação de leis e políticas públicas para formalizar normativas correcionais e penais. Nos anos de 1870 a 1930, as políticas, higienistas fizeram parte do processo de modernização das cidades brasileiras, desenvolvendo neste período novas forma de sociabilidade dos espaços públicos ${ }^{1}$ (ARAÚJO, 2014).

A proposta do Estado para o progresso nacional também passava pelas questões sociais como saúde, educação e trabalho. Nos meios médicos e jurídicos a preocupação com a infância pobre, estava ligada aos aspectos higiênicos, uma vez que o Estado tentava normatizar a sociedade segundo os padrões de comportamento e hábitos cotidianos da sociedade paraense em ascensão. E para que isso acontecesse de fato, a desordem social e moral nos centros urbanos deveria ser eliminada. Sendo assim, construiu-se a ideia de inserir o menor nas frentes de trabalho para aprender um ofício e acabar com o ócio (ARAÚJO, 2014).

Os menores eram enviados ao arsenal da Marinha para se alistarem na Companhia de Aprendizes Marinheiros ou de Artífices por meio dos chefes de polícia ou Juízes de Órfãos de qualquer localidade na Província do Pará. Havia, também, os menores que chegavam à companhia em diversas situações como: órfãos, desvalidos, aprendizes, voluntários e filhos de famílias extremamente pobres ${ }^{2}$.

À medida que a criminalidade se avolumava, os aparelhos policiais e até as forças armadas entravam em ação no combate à criminalidade de menores considerados "delinquentes". Desse modo, exigiu-se do Estado que fossem criadas políticas públicas de atendimento à infância que dessem conta desta realidade, uma vez que todas as iniciativas no âmbito da infância "estigmatizada" eram de cunho privado, religioso ou filantrópico (ARAÚJO, 2014).

Sabe-se que o período supracitado ficou marcado por diversos acontecimentos sociais, econômicos e políticos no Brasil. A sociedade patriarcal da recém proclamada República galgava por interesses que vislumbravam a hegemonia da classe dominante. A população pobre do país ficou subjugada às forças dominantes de produção. Entretanto, todo o crescimento socioeconômico não acompanhou o desenvolvimento da sociedade como um todo, desvelando que sobre essa realidade ainda havia muito a se fazer (ARAÚJO, 2014).
Higienismo foi uma medida que influenciou muitas práticas e políticas públicas fortemente implantadas no Brasil. Pode-se dizer que o higienismo, como uma forma de pensar,

é um desdobramento da "medicina social". A urbanização sem planejamento decorrente da industrialização emergente que acontecia no Brasil no final do século XIX e

início do século XX traz como consequência problemas de toda ordem, entre os quais se destacam os de natureza médica: as condições sanitárias ameaçadoras e os surtos epidêmicos. Morria-se de uma ampla variedade de doenças, como varíola, febre amarela, malária, tifo, tuberculose, lepra, disseminadas mais facilmente pela concentração urbana. (ALVES, 2012, p. 3302)

Os chefes de polícia das Províncias, como da corte, tinham a função de recolherem menores abandonados, órfãos e desvalidos das ruas ou em situações em que o menor não possuísse nenhum parente ser seu tutor. Os chefes de polícia os enviavam não somente para a Companhia de Aprendizes

Marinheiros, mas outras instituições que acolhiam esses menores, como a Santa Casa de Misericórdia, o Instituto Paraense dos Educandos Artífices, Companhia de Aprendizes Artífices do Arsenal de Marinha, Liceu Paraense, Nossa Senhora do Amparo e outras da província do Pará. 
O ideal republicano consolidou, portanto, a necessidade de inserir o menor criminoso na atividade produtiva, de educá-lo, corrigi-lo e discipliná-lo, preparandoo para um futuro digno, condizente com o contexto social daquela época. O mundo do trabalho se tornou importante por objetivar o aperfeiçoamento do caráter de menores em situação de risco e por lhes ensinar um ofício.

\subsection{Instituto orfanatório do outeiro}

O Instituto Orfanológico do Outeiro, criado por decreto em 1904, desde sua aprovação ficou em um longo período em fase de adaptação, haja vista que esse foi instalado em um prédio já existente desde meados do século XIX, a hospedaria para imigrantes em Outeiro, como informa a mensagem ao Congresso Legislativo do Estado do Pará, do então governador Augusto Montenegro.

\section{Foto 2: Fachada do Instituto Orfanológico}

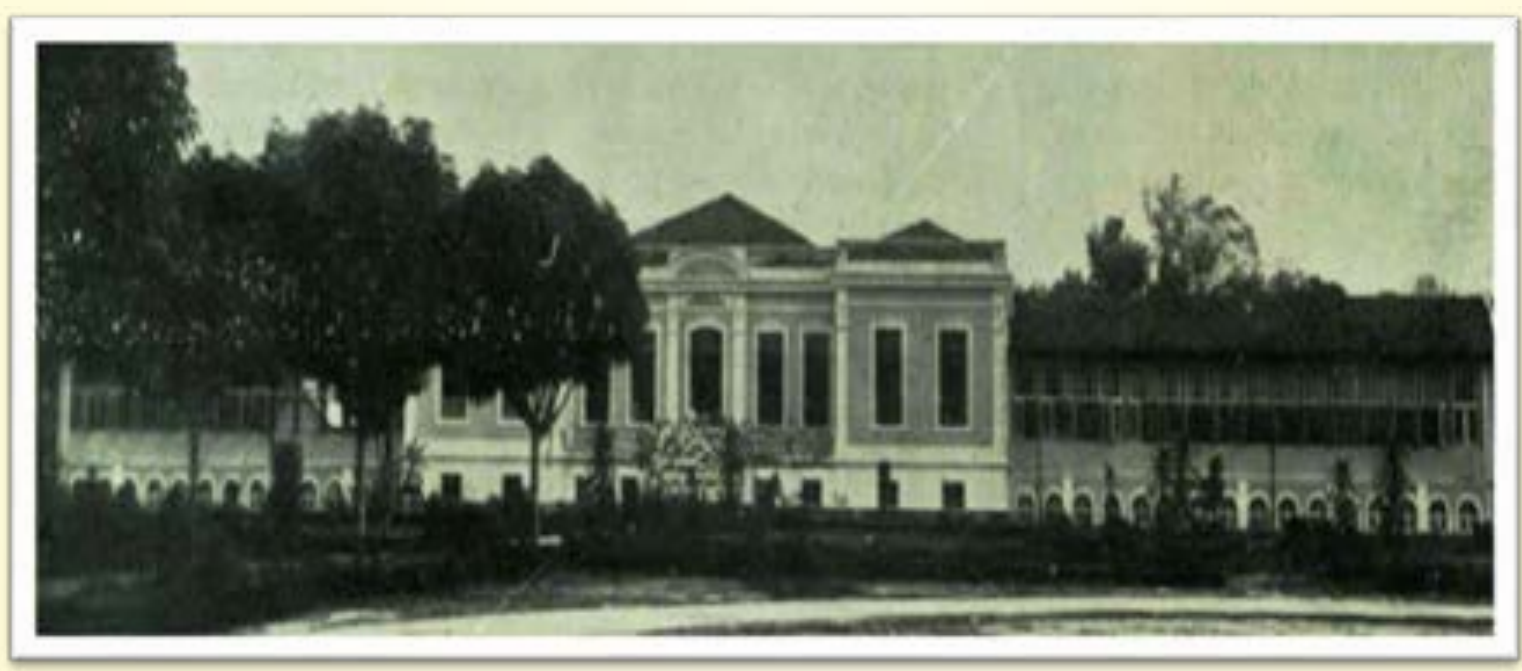

Fonte: Álbum do Pará, 1908. Biblioteca Artur Vianna. Setor de Obras Raras.

Segundo relatos oficiais do Governador Augusto Montenegro, contidos no Álbum do Pará de 1908, a principal motivação para a criação do Instituto tem relação com a carência de instituições destinada a meninos abaixo dos 12 anos de idade em Belém, o que se agravou ainda mais com a mudança no estatuto do Instituto Lauro Sodré instituição criada no século XIX que recebia meninos órfãos desvalidos, que passou a limitar o ingresso de alunos com idade a partir de 12 anos, pois meninos 
menores a essa faixa etária não conseguiam bom aproveitamento nos cursos profissionalizantes lá oferecidos (PINHEIRO; ALVES, 2014).

De acordo com a Foto 2, podemos ter uma ideia aproximada da fachada do Instituto Orfanológico pela sua imponência em um lugar simples e pouco habitado. Os jornais da época noticiaram, com muita precisão, toda a reforma do prédio assim como da sua inauguração que teve todo um requinte para receber não somente as autoridades, mas principalmente a elite local que estava a investir a favor dos mais necessitados. Nas matérias de jornais sobre o Instituto Orfanológico era relatado a qualidade de toda mobília, objetos e materiais de ensino da instituição e que eram considerados os artefatos mais modernos trazidos da França.

\section{Foto 3: Internos posando em frente ao Instituto Orfanológico do Outeiro}

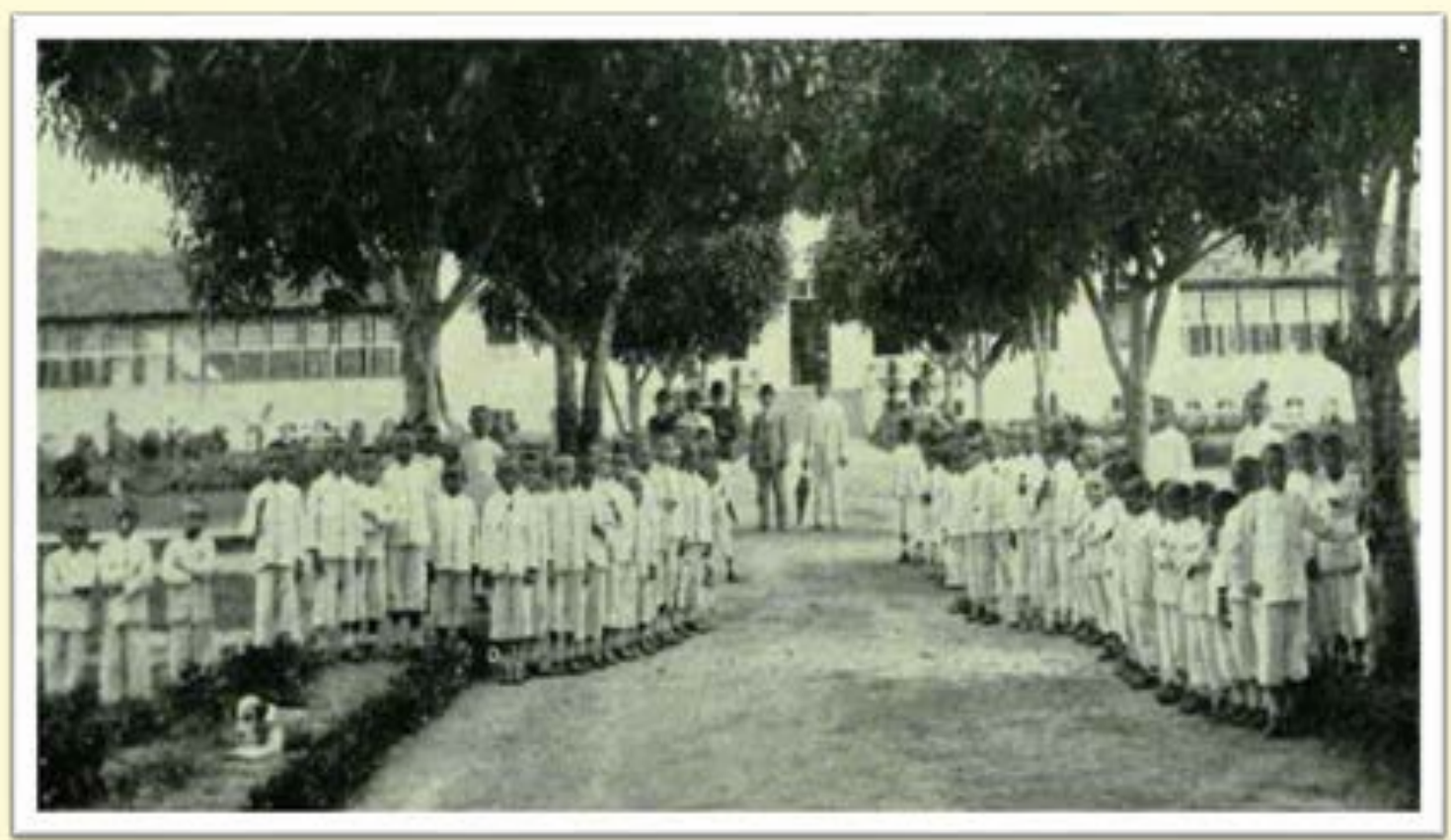

Fonte: Álbum do Pará, 1908. Biblioteca Artur Vianna. Setor de Obras Raras.

Desse modo, o Instituto Orfanológico viria suprir a demanda de meninos muito pequenos que precisavam de cuidados e educação, conforme o que foi relatado. O Instituto Orfanológico do Outeiro destinava a "educação dos menores de 6 a 9 annos, filhos de Paes pobres ou órfãos, que, a falta de recursos, vêm pedir a tutela do estado os elementos que, mais, tarde, os tornem cidadãos úteis a communhão social" (PINHEIRO; ALVES, 2014).

O Instituto Orfanológico do Outeiro era uma escola em sistema de internato, modelo que se apresenta como um regime de educação adequado ao exercício da 
vigilância e da disciplina. Na Foto 3, podemos observar o perfil de crianças que a instituição recebia. Eram crianças mestiças que variavam entre 6 a 9 anos de idade. Constatamos, ainda na Foto 3, um grupo de aproximadamente 60 crianças que foram fotografadas na frente da instituição, permite também verificar o traje branco usado pelas crianças, e ao fundo os professores e diretores da instituição.

Foto 4: Sala de aula do Instituto Orfanológico do Outeiro.

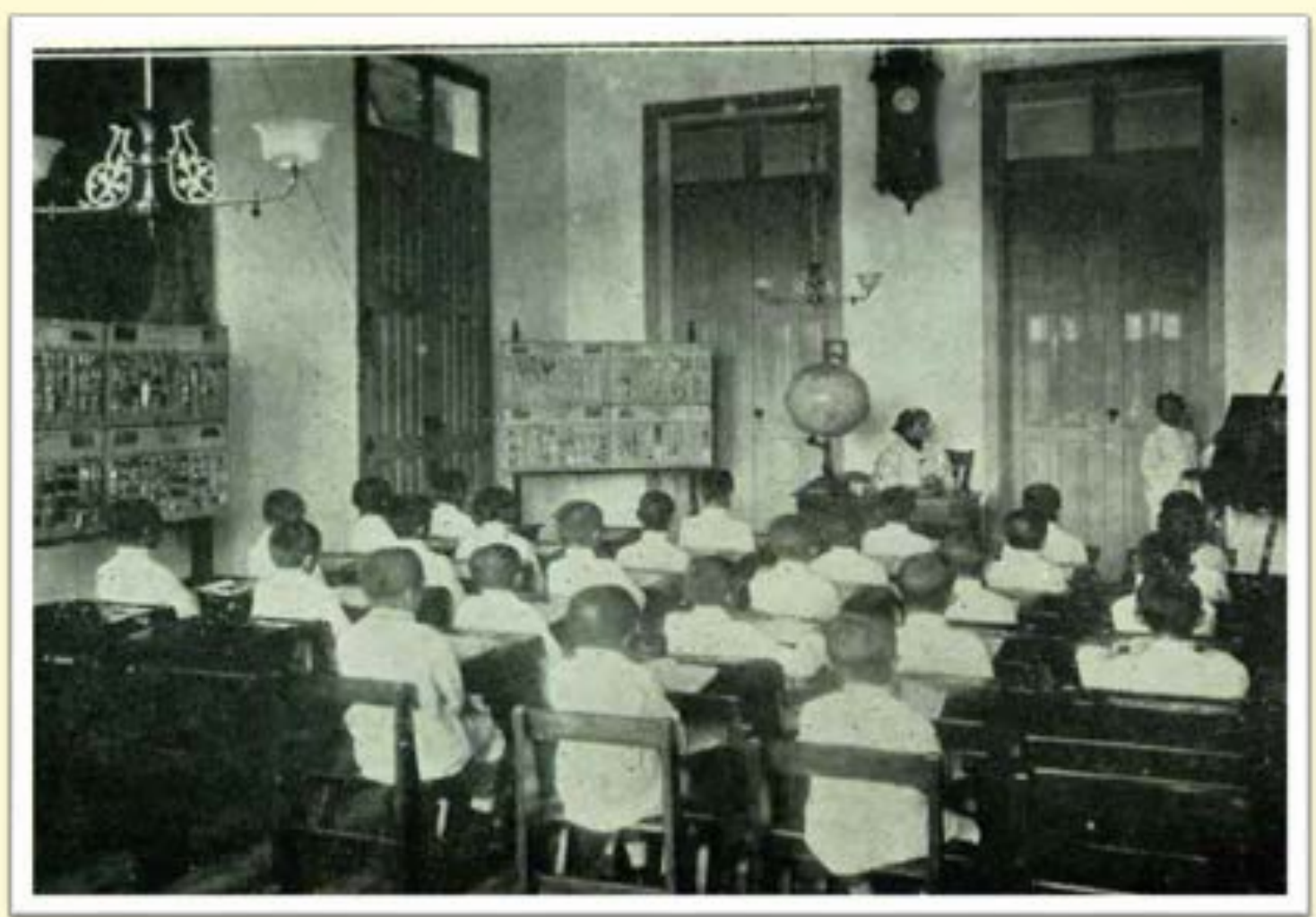

Fonte: Álbum do Pará, 1908. Biblioteca Artur Vianna. Setor de Obras Raras.

Durante todo o governo de Augusto Montenegro, divulgava-se que o Instituto era "destinado à educação e ao aparo da infância" e de fundamental relevância social, pois é o local "onde os desprotegidos vão encontrar abrigo carinhoso que não puderam receber do seio materno" (PINHEIRO; ALVES, 2014). Na Foto 4, podemos observar uma representação da sala de aula do instituto com 25 crianças uniformizadas e duas professoras ao fundo. A sala aparentemente arejada e com objetos dispostos no ambiente como artefatos escolares, já que o globo, o quadro negro e os cavaletes com ilustrações fazem da sala um lugar educativo. 


\subsection{Colégio Nossa Senhora do Amparo}

No Pará, em 1804, é criada a Casa da Caridade pelo bispo D. Manoel de Almeida Carvalho, que após uma viagem pelo interior traz para a capital 15 meninas indígenas de Aldeias do Rio Negro (posteriormente, Província do Amazonas) para educá-las. Contudo, o projeto de criação da "obra pia” é de autoria de seu antecessor, o bispo Caetano Brandão ${ }^{3}$.

A Casa destinada ao acolhimento de enfermos era inadequada para o atendimento de meninas. Assim, no mesmo ano, tratou-se de transferi-las para outra habitação. Com os anos, a instituição dedicou-se ao recolhimento e educação de meninas pobres da capital do Pará, afastando-se de sua finalidade original do "resgate" de indígenas. Por volta de 1838, a Casa das Educandas é transformada no Colégio de Nossa Senhora do Amparo, quando o governo do Pará assumiu a sua administração e manutenção, conforme se observa nos relatórios de Províncias da época (SABINO, 2012).

As meninas do Amparo tinham aulas de cozinha, corte, costura e confecção de flores, todas realizadas em grupo. As educandas aprendiam, ainda, a cantar (canto coral, etc.), declamar, orar, colaborar e participar dos atos religiosos, além de despenderem de suas aptidões artísticas, porém essa educação foi questionada pelo presidente da província, com o argumento de ser muito luxuosa para meninas que fora do colégio não passariam de simples empregadas domésticas.

O ensino e a educação das meninas do Colégio de Nossa Senhora do Amparo consistiam no curso primário e secundário (este ministrado a partir de 1871 quando se instala a escola normal, de onde as meninas seriam designadas professoras ou normalistas). Fazia parte do currículo o ensino de práticas de serviços e prendas domésticas, como também o ensino da religião católica, destinados à formação moral/cristã das meninas (SABINO, 2012). Na Foto 5, há a representação da aula de flores que as meninas do Colégio do Amparo tinham durante a semana. É possível observar nessa classe um grupo de 25 educandas do Amparo usando uniforme igual e distribuída harmonicamente. 


\section{Foto 5: Aula de Flores das educandas do Colégio Nossa Senhora do Amparo}

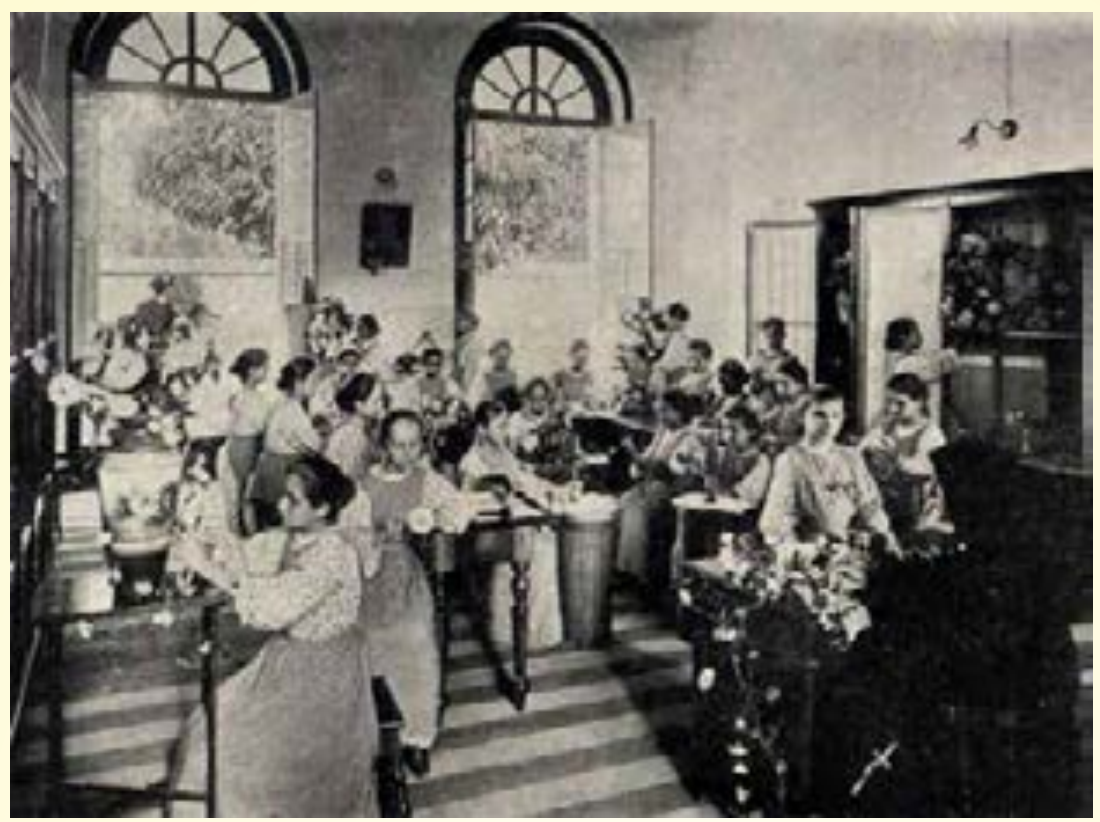

Fonte: Biblioteca Pública Artur Vianna. Setor de Obras Raras, 1868.

Foto 6: Aula de corte e costura no Colégio Nossa Senhora do Amparo em 1868.

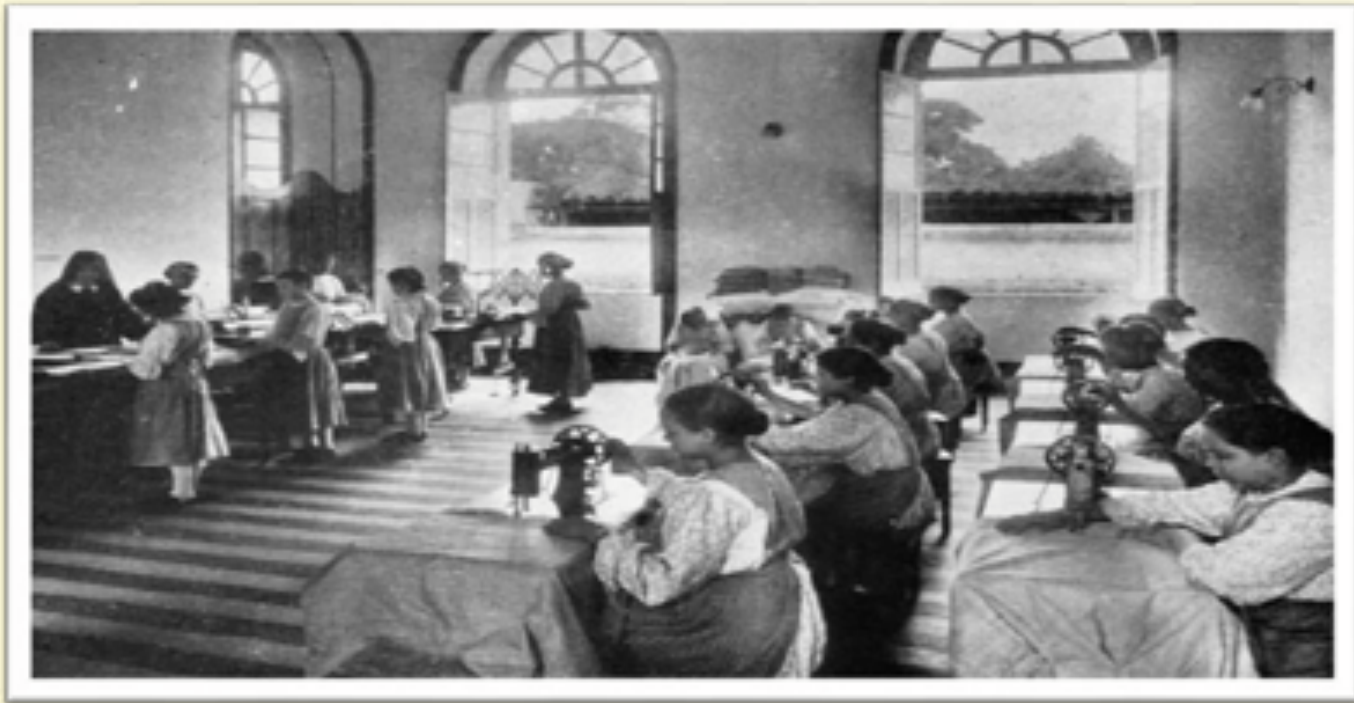

Fonte: Biblioteca Pública Artur Vianna. Setor de Obras Raras, 1868.

Já na Foto 6, podemos verificar que as educandas estavam em aula de costura que diariamente eram realizadas. O que nos chama muito a atenção nessa foto é a ordenação das meninas na sala. Enquanto algumas delas estavam sentadas a frente das máquinas de costura, outras educandas estavam junto das Irmãs tendo aula de corte e costura. Sabe-se que parte dessas produções (flores e costuras) era vendidas nos bazares da instituição. 
$\mathrm{Na}$ Foto 7, verificamos as educandas na cozinha, possivelmente tendo as primeiras noções de culinária na formação que elas tinham para poder ter o papel de mães de família ou de damas de companhia. No que se refere às estratégias de disciplinamento no Colégio Nossa Senhora do Amparo, havia regras de conduta rigorosas às meninas, expressas no regimento. Quando a direção considerava as alunas incorrigíveis e insubordinadas, essas sofriam graves punições. Nos documentos da instituição de 1875, podemos observar um caso da menina Ana Brasil que após ameaçar as companheiras, chegando inclusive a maltratá-las fisicamente, uma menina de 7 anos foi castigada rigorosamente e, mostrando-se incapaz de se corrigir, foi expulsa da instituição (SABINO, 2012).

\section{Foto 7: Aula de prendas domesticas para as educandas do Colégio Nossa Senhora do} Amparo em 1868.

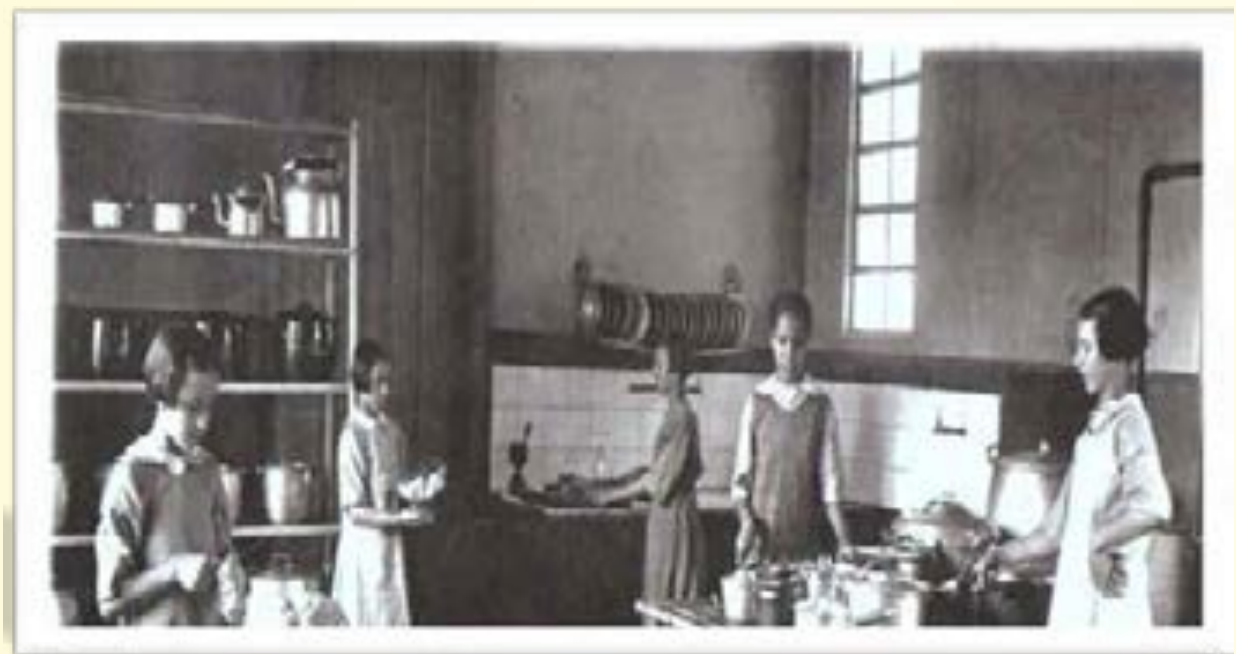

Fonte: Biblioteca Pública Artur Vianna. Setor de Obras Raras, 1868.

\subsection{Orphelinato paraense}

No ano de 1893, é criado pelo intendente Antônio Lemos uma casa para atender órfãs, denominada Orphelinato Paraense, criada por iniciativa de uma associação formada por importantes famílias da sociedade paraense, chamada "Associação Protectora dos Orphãos", instituição filantrópica que tinha como objetivo abrigar meninas órfãs e desvalidas. Porém, poucos anos depois, em virtude das dificuldades enfrentadas pela associação, o governo municipal resolveu assumila, transformando-a, a partir de então, num dos mais importantes e polêmicos projetos da municipalidade, confiando à Ordem Religiosa Filhas de Sant'Anna a sua direção interna. 
Entre os critérios de aceitação das órfãs a serem amparadas pelo Orphelinato seria que "em primeiro lugar no Orphelinato serão admitidas órfãs de pai e mãe, qualquer que seja a idade, religião e nacionalidade, em segundo lugar e nas mesmas condições, as órfãs de pai, e finalmente as de mãe, cujos pais nada tenham para mantê-las e educá-las (MONTEIRO, 2013).

Na Foto 8, é possível observamos a magistral fachada da instituição que estava de acordo com as normas arquitetônicas dos prédios escolares e atendia aos princípios higienistas. Afastado do centro da cidade de Belém, o prédio do Orphelinato Paraense tinha muitas janelas que evitava, assim, a proliferação de doenças.

\section{Foto 8: Fachada completa do Orphelinato Paraense}

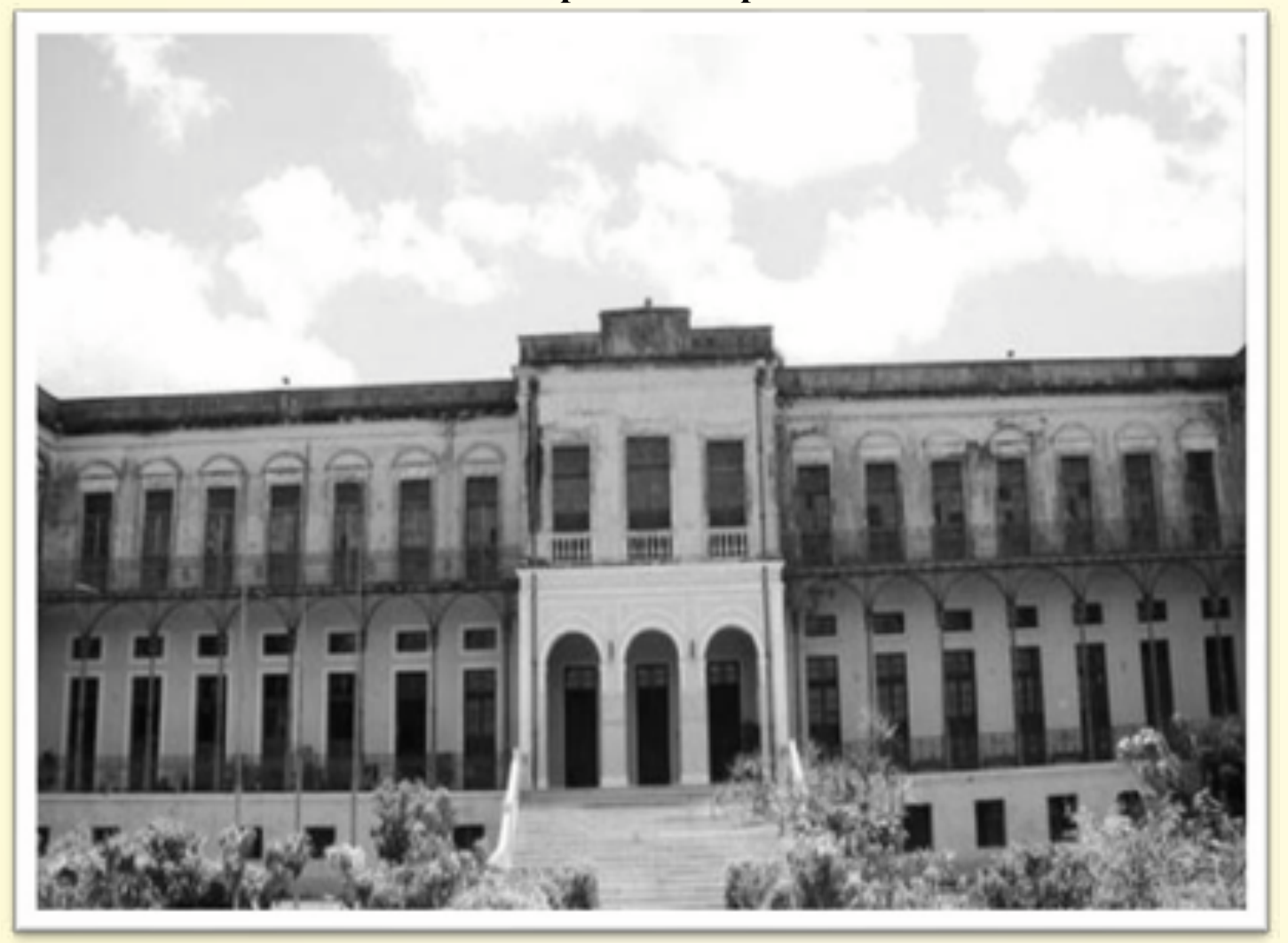

Fonte: Biblioteca Pública Artur Vianna. Setor de Obras Raras, 1892.

O Estatuto da Associação Protetora dos Órfãos afirmava ainda que os órfãos receberiam da Associação benefícios como "casa, mesa, luz, vestuário, instrução primária, ensinando-se aos do sexo feminino toda sorte de costura, chá, prendas de agulha, e serviços domésticos”. Podemos observar, também, nesse excerto, que a educação para as meninas órfãs era pensada de forma distinta da educação para os meninos órfãos.

O Orphelinato também pode ser entendido como uma estratégia higienista, visto que iria retirar e livrar a sociedade de órfãos entregues ao vício e ao crime, por 
isso "enxugai as lágrimas da pobreza, suavizai a sorte da orfandade, erguei da miséria esses entesinhos, a quem a mão da fatalidade, por vezes arroja ao abismo dos infortúnios, no isolamento da vida entregues ao vício e ao crime" (MONTEIRO, 2013). Na foto 9, visualizamos a entrada do Orphelinato Paraense, que era amplamente divulgado como uma instituição enquadrada nos princípios do higienismo. A instituição serviu de internato para meninas, sendo, inclusive, destinado para receber meninas que tinham condições de bancar financeiramente sua formação. As educandas que ali eram formadas recebiam uma educação refinada e, portanto, adequada para as meninas filhas de elite.

\section{Foto 9: Entrada do Orphelinato Paraense}

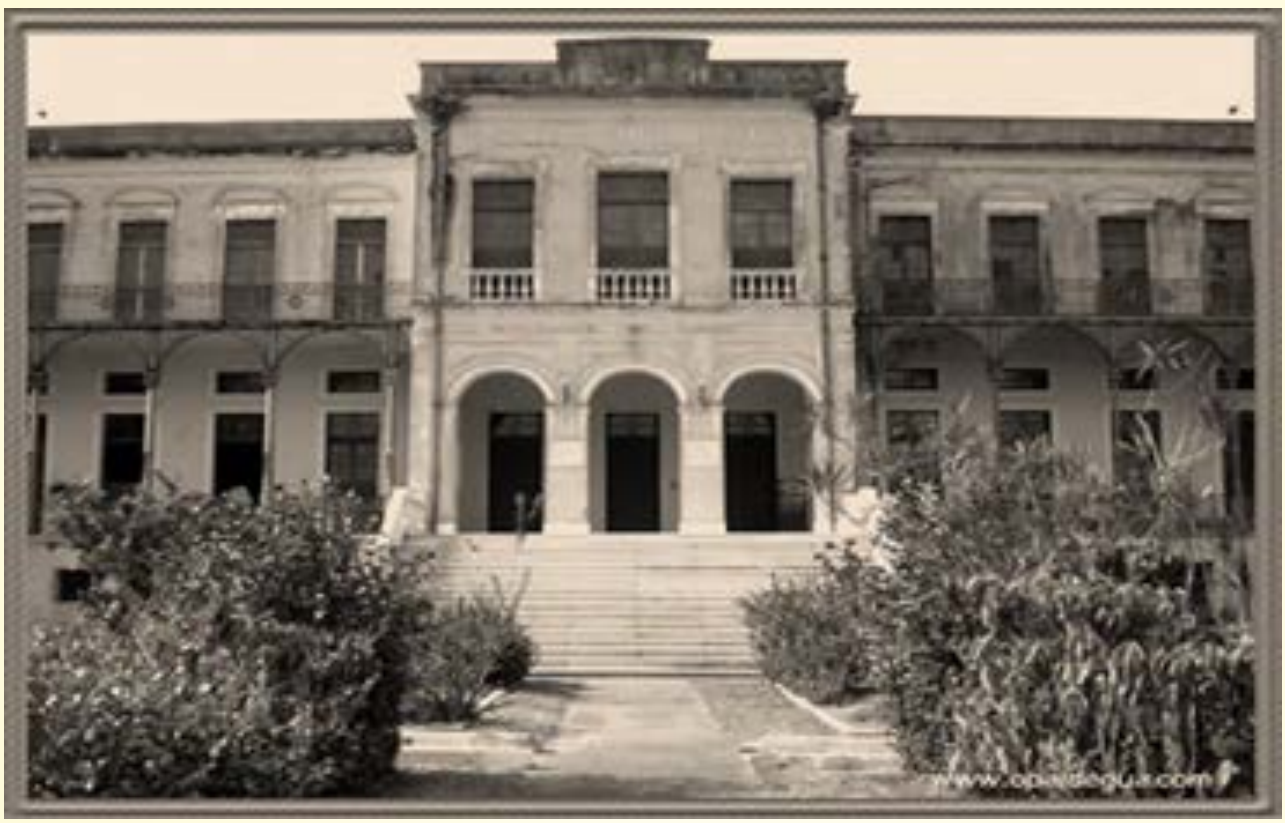

Fonte: Biblioteca Artur Vianna, 1892

\subsection{Instituto de proteção e assistência à infância do Pará}

No Pará, em 1912, o jovem médico Pediatra, Ophir Pinto de Loyola, que, de um lado, sensibilizado com a situação de abandono das crianças órfãs, pobres e desvalidas, e de outro, do quadro de desnutrição e falta de higiene vivida pelas crianças que atendia na Santa Casa de Misericórdia do Pará, funda um estabelecimento de caridade e assistência à criança - o Instituto de Proteção e Assistência à Infância do Pará (MARTINS, 2000).

Similar ao Instituto criado no Rio de Janeiro pelo médico Moncorvo Filho, o IPAI do Pará tinha o objetivo de auxiliar as crianças desvalidas e orientar as mães 
nos princípios da puericultura, tão necessários à grandeza de uma raça, e tão garantidoras do futuro de uma nação forte e civilizada. Pela abnegação e sensibilidade com a criança carente do Estado do Pará e por ser considerado pioneiro na proteção materno-infantil, coube-lhe o título de "Pai da Pediatria no Pará" (BORDALO, 2002).

$\mathrm{Na}$ foto 10 , é possível identificar o grupo de médicos higienistas do Pará que fazia parte o IPAI. Sentados, o Dr. Ophir Loyola, primeiro diretor, à direita, o Dr. Penna de Carvalho, chefe de clínica, à esquerda. De pé, o Dr. Evaristo Silva, chefe de clínica, à direita, o cirurgião dentista, Dr. Raymundo Cabral, chefe do gabinete dentário, à esquerda.

\section{Foto 10: Corpo Clínico do Instituto de Proteção e Assistência à Infância do Pará.}

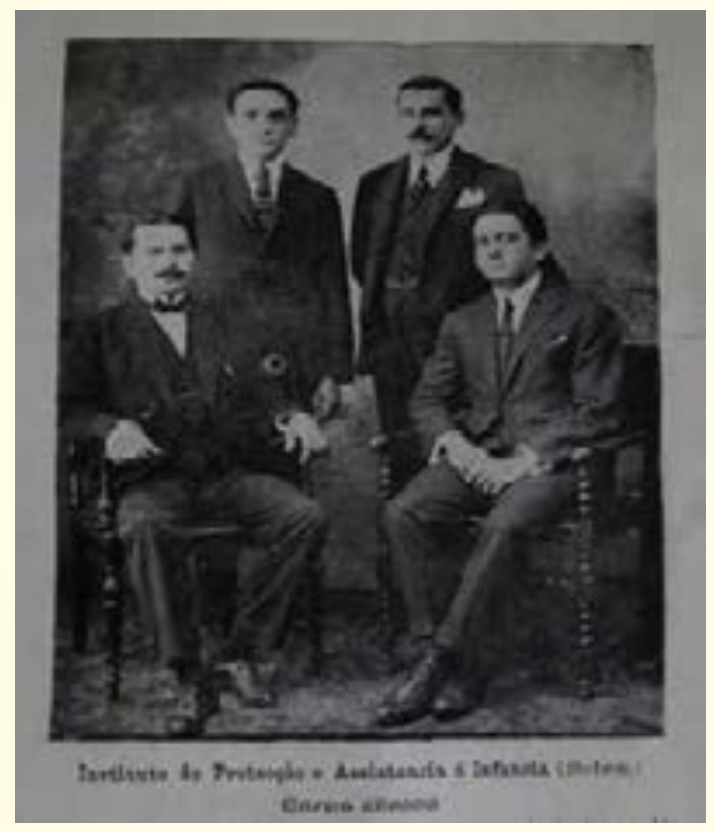

Fonte: Revista Pará Médico, 1912 (Arquivo Público Artur Vianna)

O IPAI é uma instituição privada, de caráter filantrópico, que, nascendo sob a bandeira da República e, sobretudo dos valores positivistas, encontra respaldo para sua criação em ideias da medicina higienista. É o início do conflito entre caridade e filantropia. Enquanto a primeira era campo exclusivo das Irmãs de Caridade, a segunda tem compromisso com a ciência. Inicia-se uma campanha contra os asilos de caridade e o sistema de Roda, levada a cabo por médicos e juristas (MARTINS, 2006). A questão da racionalização da saúde do menor é levantada devido às altas taxas de mortalidade infantil, tanto na sociedade em geral quanto nos asilos. 
Nesse cenário, sobressaía-se o papel dos médicos higienistas no atendimento das crianças pobres. Dispostos a enfrentar o "problema da infância" por meio de medidas higienizadoras, tais médicos defendiam não apenas a assistência maternoinfantil, mas também proposições a respeito da educação das mães, com vistas à formação física e moral dos filhos.

A atuação desses médicos higienistas foi o que instituiu o novo modelo filantrópico de assistência, que iria combinar intervenção pública, filantropia e ciência médica. Fundam-se nessa época as bases da puericultura no Brasil, definida como a ciência que trata da higiene física e social da criança. Nascido na Inglaterra e na França no século XVIII, a base da puericultura era na orientação à higiene da maternidade e da infância (ALVES, 2013).

\section{Foto 11: Primeira Sede do Instituto de Proteção e Assistência à Infância do Pará.}

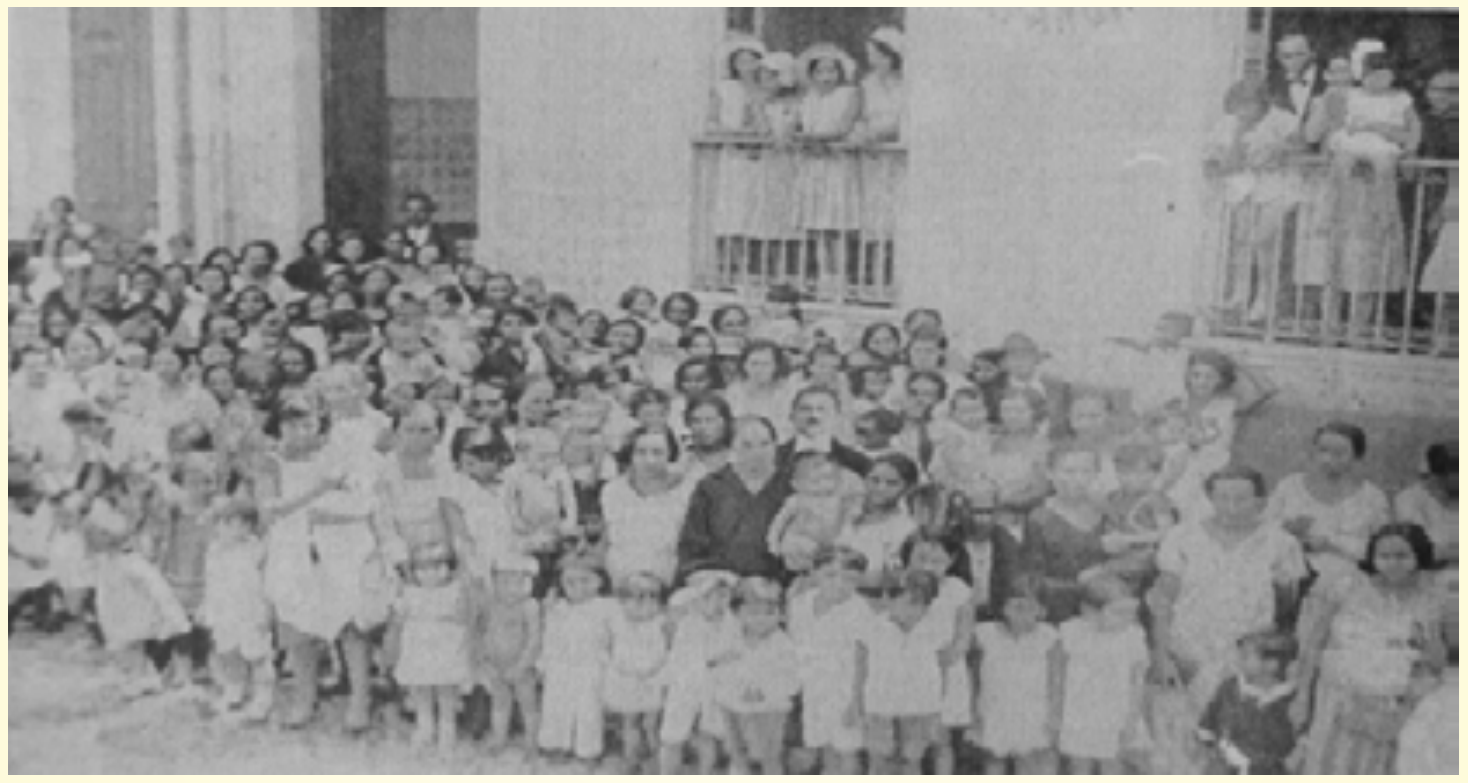

Fonte: Revista Pará Médico, 1912. Arquivo Público Artur Vianna.

O Instituto de Proteção e Assistência à Infância do Pará era uma instituição filantrópica que foi reconhecida como de utilidade pública em 1912. Essa foi indubitavelmente a grande obra de Ophir de Pinto Loyola no Pará. Ali consolidou cada vez mais sua política na assistência médico-social à infância e fez valer os seus princípios em relação ao desenvolvimento saudável da criança.

$\mathrm{Na}$ atuação como diretor do Instituto de Proteção e Assistência à Infância do Pará e da Santa Casa de Misericórdia do Pará irradiava suas ideias, suas denúncias, seus projetos, sua influência no campo da proteção à infância na Amazônia paraense 
(ALVES, 2013). Na foto 11, verificamos a primeira casa que funcionou o IPAI sob a direção Dr. Ophir Loyola, fundador, rodeado de crianças e mães em 1912. A fotografia indica que, embora funcionando em uma casa simples, o IPAI já no primeiro ano de fundação atendia um número significativo de crianças pobres.

Um homem de ciência, à frente de seu tempo, imprimindo uma marca própria na sua atuação como médico pediatra, Ophir Pinto de Loyola foi um defensor da assistência médico-social à criança pobre. Na atuação como diretor da Santa Casa de Misericórdia do Pará e professor da Cadeira de Pediatria Clínica da Faculdade de Medicina e Cirurgia do Pará irradiava suas ideias, suas denúncias, seus projetos, sua influência no campo da proteção e assistência à infância pobre. Dotado de espírito renovador e progressista, destacou-se nos estudos das doenças infantis, sobretudo as doenças tropicais que atingiam as crianças da região amazônica.

\section{Foto 12: Primeira Sede do Instituto de Proteção e Assistência à Infância do Pará.}

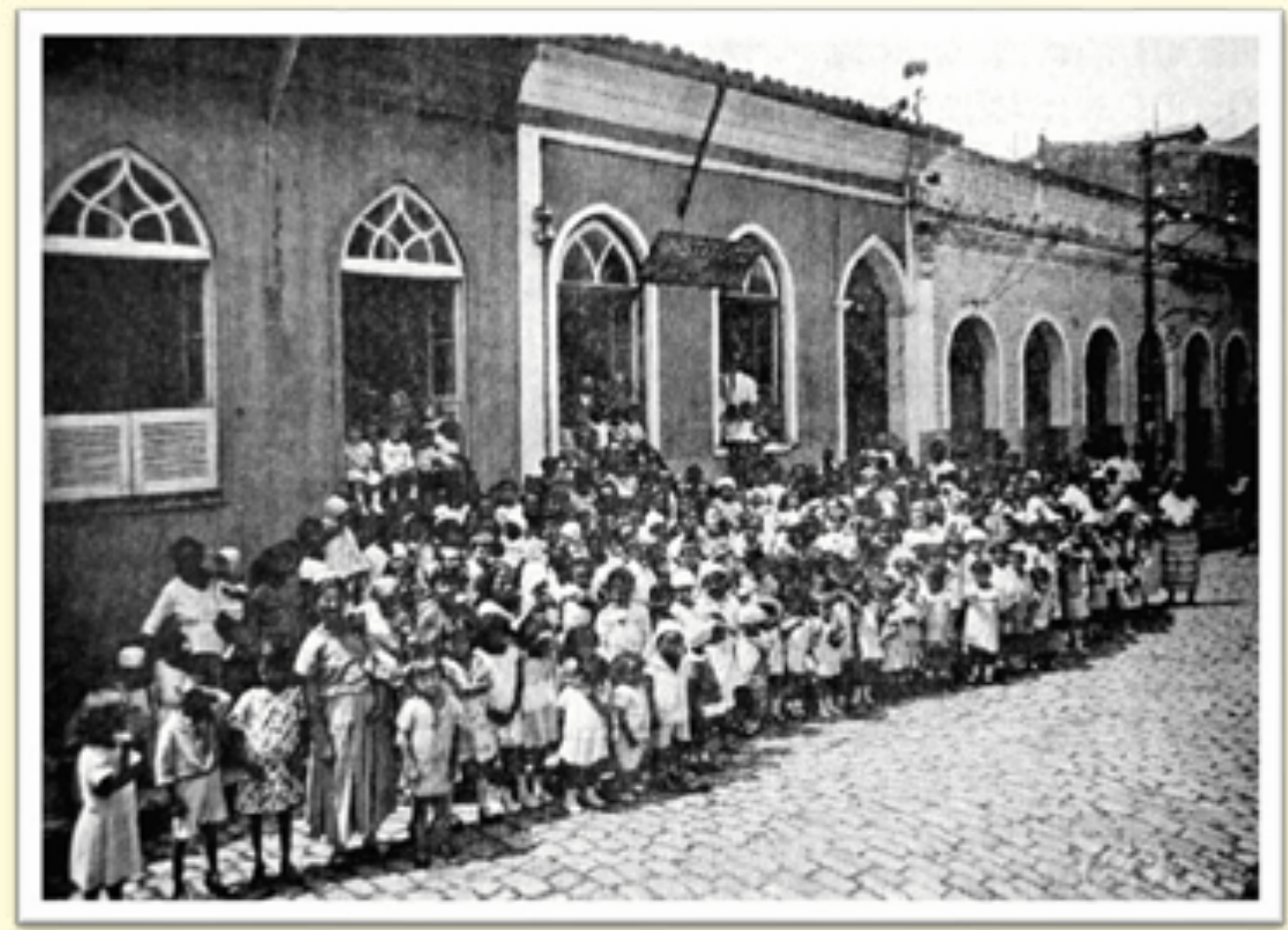

Fonte: Revista Pará Médico, 1932. Arquivo Público Artur Vianna.

Na segunda casa do IPAI (Foto 12), em 1933, já tinha credibilidade pelas suas ações no combate a mortandade infantil. Com a ajuda das Damas da Sociedade o IPAI, havia atendido muitas crianças com vacinações e outros atendimentos. Na foto podemos observar que a maioria das crianças atendidas era mestiça e na faixa etária de 1 a 7 anos. 
No caso da história social das crianças desvalidas no Pará como a criação do IPAI, resultava de uma política social, educacional e econômica pautada no progresso e nas ideias de civilização e modernidade. Para essa nova sociedade, que tentava superar a ideia de que a Amazônia é terra de índio e que estava à margem da história, como dizia Euclides da Cunha, era preciso transformar as crianças em cidadãos úteis para o desenvolvimento da nação.

Ophir Pinto de Loyola foi um defensor da assistência médico-socialeducacional às crianças pobres, desvalidas, órfãs, maltratadas, abusadas, defeituosas e enjeitadas. Um homem de ciência, à frente de seu tempo, imprimindo uma marca própria na sua atuação como médico pediatra. Iniciou uma intensa atuação a favor da higiene infantil e de uma Puericultura (medicina moderna) no atendimento da criança desvalida no Pará. Ophir Loyola é tido hoje como o grande missionário da causa da infância desvalida. A terceira seda do IPAI do Pará (foto 13) teve sua ampliação atendida com recursos garantidos pela elite local.

\section{Foto 13: Terceira Sede do Instituto de Proteção e Assistência à Infância}

\section{do Pará}

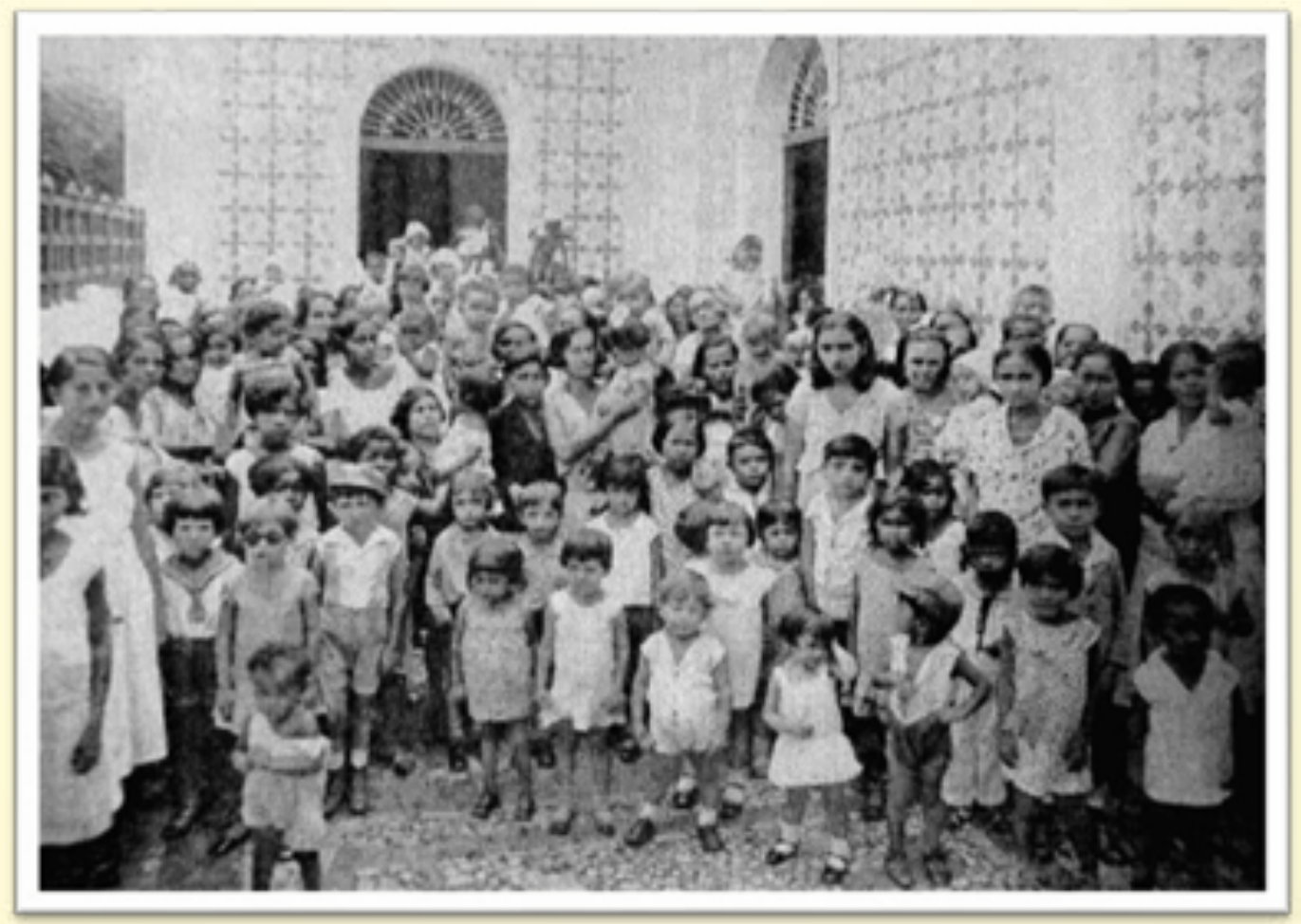

Fonte: Revista Pará Médico, 1933. Arquivo Público Artur Vianna. 


\section{CONSIDERAÇÕES FINAIS}

A racionalização da assistência era indiscutivelmente um imperativo do século XIX. No Pará, assim como por todo o Brasil, o ideário republicando destacava a criança como sujeito de processo de civilização. Salvá-la das mazelas sociais era um dos objetivos centrais. Daí a necessidade da criação de inúmeras instituições para abrigar, educar e proteger a infầncia.

A pesquisa realizada sobre a historiografia da infância e das instituições criadas no século XIX e XX no Pará destacada neste estudo, mostra-se que nessa área de estudos ainda são tímidas as produções desenvolvidas. Temos muito a investigar sobre o atendimento da criança órfã e desvalida. Há, para isso, muitos documentos oficiais e não oficiais que precisam ser analisados para que possamos entender parte dessa infância que foi silenciada pela nossa história.

Sendo assim, termino meu artigo divulgando uma carta de recomendação aos pesquisadores que querem se atirar no campo da História da Infầncia. A carta não será como a de Mario de Andrade que escreve para Mario Bandeira, demonstrando seu encantamento pela cidade de Belém nos anos 20 do século passado. Será uma carta que estimula aos que querem remar no universo da História da Infância e da Sociologia da infância.

Caros Colegas, nos estudos sobre a Infância alguns elementos são indispensáveis na construção da pesquisa e escrituração da história da Infância. Portanto, recomendo aos pesquisadores principiantes:

1. Procure colocar em discussão as formas com as quais a historiografia, a sociologia, a psicologia, a literatura, a pedagogia enfim, quase todos os ramos disciplinares das ciências humanas abordam a História da infância enquanto objeto de estudo.

2. Se sua pesquisa é histórica, defina claramente o período histórico e busque se amparar teoricamente nos autores da história da infância.

3. Definido o seu campo de investigação sobre a infância, faça inicialmente um estudo exploratório das fontes para sua pesquisa, pois é ela que vai definir o seu corpus de pesquisa.

4. Elabore um estado da arte sobre o seu objeto de investigação sobre a infância, ou seja, investigue as produções de estudiosos locais, regionais, nacionais e 
internacionais.

5. Sobre a história da infância, busque ampliar seus documentos para compor o corpus da pesquisa como, por exemplo, material iconográfico, relatórios, atas, cartas, desenhos, cartilhas, manuais etc.

6. Incentive a formação de arquivos em suas escolas, bibliotecas e em outros ambientes de sua atuação, com documentos que possam contribuir para a preservação da memória da infầncia.

7. Se sua pesquisa é sobre a criança contemporânea e que tem como objetivo as culturas infantis, por exemplo, indico que é preciso dar voz às crianças, conhecer quem são, como vivem, como é seu grupo de interação, quais suas preferências e o que elas pensam a respeito de si mesmas, das relações com seus pares e com os adultos, acerca do mundo em que vivem entre outros. Nesse movimento entrelaçam-se histórias, narrativas, interpretações, sentidos, ações sobre a criança.

8. Nas entrevistas com crianças não cometa o erro de silenciar a criança, ou seja, de achar que elas são, do ponto de vista do desenvolvimento humano, demasiadamente imaturas e incapazes de dar seu testemunho.

9. Um dos principais desafios das pesquisas é o aspecto Ético no contexto de entrevistas com crianças, pois elas têm o direito de serem tratadas de forma ética e moralmente aceitável.

10. Ouse na análise do seu corpus, isso é, seja criativo nas análises dos dados e na escritura do seu texto. No mais, muita dedicação, altivez e serenidade para construir um trabalho de qualidade e que contribua para a História da infância.

Sucesso a todos e todas!!!!!!!!

Um abraço. 


\section{REFERÊNCIAS}

ALVES, Laura Maria Silva Araújo. Proteção e Assistência à Infância Desvalida no Pará (1912-1934). In: SEMINÁRIO NACIONAL DE ESTUDOS E PESQUISAS "HISTÓRIA, SOCIEDADE E EDUCAÇÃO NO BRASIL", 9., 2012, João Pessoa. Anais eletrônicos. João Pessoa: UFPB, 2012. p. 3295-3313. Disponível em: < http://www.histedbr.fe.unicamp.br/acer_histedbr/seminario/seminario9/PDFs/4.22.pd $\mathrm{f}>$

ALVES, Laura. M. S. Araújo; CHAGAS, Ainnê C. P.; VIANA, Carmeci dos Reis. A morte de anjinhos: análise da mortandade infantil no Pará nos Livros Perpétuos do Cemitério de Santa Isabel (1909-1914). In: ENCONTRO MARANHENSE DE HISTÓRIA DA EDUCAÇÃO, 8., 2015, São Luís. Anais ... . São Luís: NEDHEL; UFMA, 2015.

ARAÚJO, Telmo Renato da Silva. Entre a criminalidade e o cotidiano militar: a inserção de menores nas forças armadas no Pará em finais do século XIX. Belém: UEPA, 2014.

BARBOSA, Andreson Carlos Elias. O instituto paraense de educandos artífices e a morigerância dos meninos desvalidos na Belém da Belle Époque. 2011. 227 f.. Dissertação (Mestrado) - Instituto de Ciências da Educação, Programa de PósGraduação em Educação, Universidade Federal do Pará. Belém, 2011.

BEZERRA NETO, José Maia. As luzes da civilização: instrução pública, institutos e asylos católicos no Pará (1870/1889). 1994. Monografia (Especialização) - Instituto de Filosofia e Ciências Humanas, Programa de Pós-Graduação em Sociologia e Antropologia, Universidade Federal do Pará. Belém, 1994.

BORDALO, Alípio Augusto (org.). A sociedade médico-cirurgica e a medicina no Pará. Belém: Gráfica Sagrada Família, 2002.

BORDALO, Alípio Augusto. A misericórdia paraense, ontem e hoje. In: BORDALO, Alípio Augusto (org.). A sociedade médico-cirurgica e a medicina no Pará. Belém: Gráfica Sagrada Família, 2000.

CANCELA, Cristina Donza. Uma cidade... muitas cidades: Belém na economia da borracha. In: BELTRÃO, Jane Felipe; VIEIRA JR, Antonio Otaviano. (Org.).

Conheça Belém, co-memore o Pará. Belém: UDUFPA, 2008.

DEL PRIORE, Mary. História das crianças no Brasil. São Paulo: Contexto, 1999.

FERREIRA, António Gomes Alves; GONDRA, José Gonçalves. Idade da vida, infância e a racionalidade médico-higiênica em Portugal e no Brasil (século XVIIXIX). In: LOPES, Alberto; FARIA FILHO, Luciano Mendes; FERNANDES, Rogério. Para a compreensão histórica da infância. Belo Horizonte : Autêntica, 2007. 
FERREIRA, Luiz. O.; FREIRE, Maria. M. Medicina, filantropia e infância na Bahia: um hospital para crianças (1920-1930). In: SOUZA, Christiane M. C.; BARRETO, Maria Renilda Nery (orgs.). História da saúde pública na Bahia: instituições e patrimônio arquitetônico (1808-1958). Barueri: Minha Editora, 2011.

GONDRA, José Gonçalves. Medicina, higiene e educação, o escolar. In: LOPES, Elane Marta; FARIA FILHO, Luciano Mendes; VEIGA, Cynthia Greive. 500 anos de educação no Brasil. 3. ed. Belo Horizonte: Autêntica, 2003.

JURANDIR, Dalcídio. Chove nos campos de cachoeira. Rio de Janeiro: Casa Editora Vecchi LTDA, 1941.

MARCÍLIO, Maria Luiza. História social da criança abandonada. São Paulo: HUITEC, 1998.

MARQUES, Marília Luisa. Discurso médico sobre seres frágeis. Rio de janeiro: FIOCRUZ, 2000.

MARTINS, Mário Ruben de Melo. Instituto Ophir Loyola: Instituto de Proteção e Assistência à Infância do Pará. Belém: Universidade Federal do Pará, 2006.

MONTEIRO, Yara Nogueira. Violência e profilaxia: os preventórios paulistas para filhos de portadores de hanseniase. Saúde e Sociedade, São Paulo, v. 7, n. 1, jan./jul. 1998.

MONCORVO FILHO, A. História da proteção à infância no Brasil 1500-1922. Rio de Janeiro: EmprezaGraphica Editora, 1926.

MONTEIRO, Antonio Valdir. Órfãs e desvalidas: a formação de meninas no Orfanato Municipal de Belém do Pará. 2013. 277 f. Tese (Doutorado) - Programa de Pós-Graduação em Educação, Universidade Federal de Uberlândia, Uberlândia, 2013.

NASCIMENTO, Alcileide Cabral. A sorte dos enjeitados: o combate ao infanticídio e a institucionalização da Assistência às Crianças Abandonadas no Recife (17891832). São Paulo: Annablume/FINEP, 2008.

PINHEIRO, Welington da Costa. A infância nas páginas de jornal: discursos (re) produzidos pela imprensa paraense na primeira década do século XX. 2013. $149 \mathrm{f}$. Dissertação (Mestrado) - Programa de Pós-Graduação em Educação, Universidade Federal do Pará, Belém, 2013.

PINHEIRO, Welington da C. ; ALVES, Laura M. S. A. O Instituto Orfanológico do Outeiro e a educação de meninos desvalidos (1904-1922). In: ENCONTRO MARANHENSE DE HISTÓRIA DA EDUCAÇÃO, 8., 2015, São Luís. Anais ... . São Luís: NEDHEL; UFMA, 2015.

RIZZINI, Irene. O século perdido: raízes históricas das políticas para a infância no Brasil. 2. ed. São Paulo: Cortez, 2008.

RIZZINI, Irene; PILOTTI, Francisco (Org.). A arte de governar crianças: a história das políticas sociais da legislação e da assistência à infância no Brasil. In: RIZZINI, 
Irene. Crianças e menores : do pátrio poder ao pátrio dever: uma história da legislação para a infância no Brasil. São Paulo: Cortez, 2009.

SABINO, Elianne Barreto. A assistência e a educação de meninas desvalidas no Colégio Nossa Senhora do Amparo na Província do Grão-Pará (1850-1889).

2012. 157 f. Dissertação (Mestrado) - Instituto de Ciências da Educação, Universidade Federal do Pará, Belém, 2012.

SARGES, Maria de Nazaré. Belém: riquezas produzindo a belle-époque (18701912). Belém: Paka-Tatu, 2002.

SILVA, Jairo de Jesus Nascimento da. Da Mereba-ayba à variola: isolamento, vacina e intolerância popular em Belém do Pará, 1884-1904. 2009. 148 f. Dissertação (Mestrado em História Social) - Instituto de Filosofia e Ciências Humanas, Programa de Pós-Graduação em História Social da Amazônia, Universidade Federal do Pará. Belém, 2009.

SCHUELER, Alessandra Frota Martinez de. A infância desamparada no asilo agrícola de Santa Isabel: instrução rural e infantil (1880-1886). Educação \& Pesquisa, São Paulo, v. 26, n. 1, 2002.

VENÂNCIO, Renato Pinto. Famílias abandonadas: assistência à criança de camadas populares no Rio de Janeiro e em Salvador : séculos XVIII e XIX. Campinas, São Paulo: Papirus, 1999.

VIANA, Artur. A Santa Casa de Misericórdia Paraense : notícia histórica 16501902. Belém, 1909. 